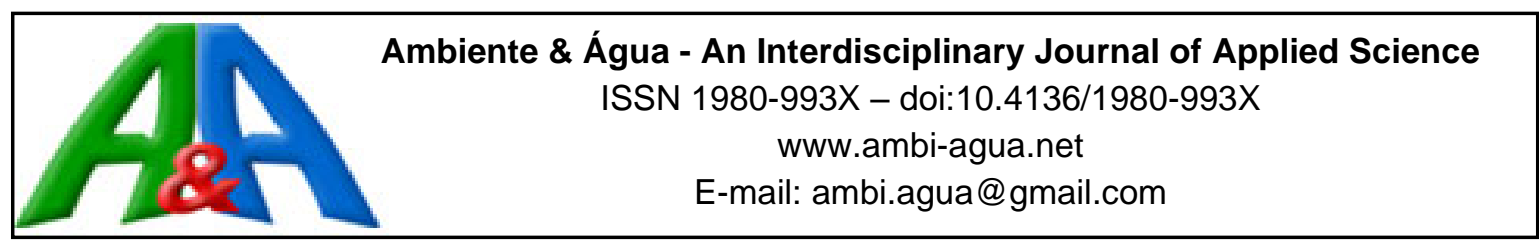

\title{
Energy potential of biogas and sludge from UASB reactors in the State of Paraná, Brazil
}

\author{
ARTICLES doi:10.4136/ambi-agua.2398
}

Received: 28 Mar. 2019; Accepted: 25 Nov. 2019

\section{Lucas Sampaio Lopes ${ }^{1(D ;}$; Andre Pereira Rosa ${ }^{1 *}$; Júlia Silva Marco ${ }^{2}$; Gustavo Rafael Collere Possetti ${ }^{3,4}$; Tayane Cristiele Rodrigues Mesquita ${ }^{1}$}

\footnotetext{
${ }^{1}$ Departamento de Engenharia Agrícola. Universidade Federal de Viçosa (UFV), Avenida Peter Henry Rolfs, s/n, CEP: 36570-900, Viçosa, MG, Brazil. E-mail: lucasctu@gmail.com, tayanemesquita@yahoo.com.br ${ }^{2}$ Departamento de Geografia.Universidade Federal de Viçosa (UFV), Avenida Peter Henry Rolfs, s/n, CEP: 36570-900, Viçosa, MG, Brazil. E-mail: juliasmarco18@gmail.com

${ }^{3}$ Gerência de Pesquisa e Inovação. Companhia de Saneamento do Paraná (Sanepar), Rua Engenheiro Antônio Batista Ribas, n 151, CEP: 82800-130, Curitiba-PR, Brazil. E-mail: grcpossetti@gmail.com

${ }^{4}$ Programa de Mestrado Profissional em Governança e Sustentabilidade. Instituto Superior de Administração e Economia do Mercosul (ISAE), Avenida Visconde de Guarapuava, n 2943, CEP: 80010-100, Curitiba, PR, Brazil. E-mail: grcpossetti@gmail.com

*Corresponding author. E-mail: andrerosa@ufv.br
}

\begin{abstract}
Upflow Anaerobic Sludge Blanket (UASB) reactors are widely used for domestic sewage treatment in Brazil, and generate sludge and biogas as by-products. Typically, the sludge is sent to sanitary landfills, and the biogas is burned in flares. This study assessed the energy potential of these by-products in sewage treatment plants (STPs) located in the state of Paraná, Brazil. First, an overview of biogas energy recovery potential in a full-scale STP based on UASB reactors was carried out. Afterwards, a total of 239 STPs in the state of Paraná were assessed, and the energy potential of the by-products was estimated by a mathematical model. Data were spatially classified using ArcGIS®, taking into account the different effluent characteristics (worst, typical and best scenario), sludge dehydration systems (drying bed and centrifuge) and sizes (small, medium and large). Among the states in Brazil, Paraná presented the highest biogas potential, although nowadays it exploits only $0.4 \%$ of its capacity. Biogas was the main by-product generated by UASB reactors in Paraná, and if used in the entire state, it could supply the energy demands of a city with 111,000 inhabitants. Biogas corresponded to 65, 64 and 74\% of the total potential (sludge and biogas) for small, medium and large STPs, respectively. The study of the energy potential of the by-products associated with GIS tools positively contributes to the decision-making process in sanitation management and to improve energy sustainability.
\end{abstract}

Keywords: energy recovery, sewage treatment plant, UASB reactor.

\section{Potencial energético do biogás e lodo de reatores UASB no Estado do Paraná, Brasil}

\section{RESUMO}

Os reatores anaeróbios de fluxo ascendente e manta de lodo (UASB) são amplamente utilizados para tratamento de esgoto doméstico no Brasil e geram como subprodutos lodo e biogás. Normalmente o lodo é enviado para aterros sanitários e o biogás é queimado em flare. 
O objetivo desse estudo foi avaliar o potencial energético desses subprodutos em estações de tratamento de esgoto (ETEs) localizadas no estado do Paraná, Brasil. Inicialmente foi elaborada uma visão geral do potencial de recuperação de energia do biogás em ETEs, em escala plena, que utilizam reatores UASB. Posteriormente, 239 ETEs no estado do Paraná foram avaliadas, sendo o potencial energético dos subprodutos estimado por um modelo matemático. Os dados foram espacialmente classificados utilizando o ArcGIS ${ }^{\circledR}$, levando-se em consideração as diferentes características do efluente (pior cenário, cenário típico e melhor cenário), sistemas de desidratação do lodo (leito de secagem e centrífuga) e tamanhos (pequeno, médio e grande). Entre os estados do Brasil, o Paraná apresentou o maior potencial energético de biogás, embora explore apenas $0,4 \%$ de sua capacidade. O biogás é o principal subproduto gerado pelos reatores UASB no Paraná de modo que, caso utilizado em todo o estado, poderia suprir a demanda de energia de uma cidade com 111.000 habitantes. O biogás correspondeu a 65, 64 e 74\% do potencial energético total (lodo e biogás) para as pequenas, médias e grandes ETEs, respectivamente. $\mathrm{O}$ estudo do potencial energético dos subprodutos avaliados associado à utilização de ferramentas de SIG contribui positivamente para o processo de tomada de decisão na gestão de saneamento e para melhorar a sustentabilidade energética.

Palavras-chave: estação de tratamento de esgotos, reator UASB, recuperação de energia.

\section{INTRODUCTION}

Among the technological alternatives for sewage treatment in Brazil, the anaerobic systems can be highlighted (Santos et al., 2016), especially with the wide use of upflow anaerobic sludge blanket reactors (UASB). Chernicharo et al. (2018) have recently accounted for more than 650 full-scale UASB based STPs with treatment capacity of $43 \mathrm{~m}^{3} \mathrm{~s}^{-1}$, corresponding to nearly 23 million inhabitants. The interest in such systems is particularly associated with their low costs for installation and operation, as well as the low demand for area and energy consumption (Khan et al., 2011).

The expansion of STPs that use anaerobic treatment systems in Brazil has increased the generation of by-products of anaerobic digestion, such as biogas and sludge (ROSA et al., 2018). These by-products can be used for energy recovery purposes, which has raised interest in their management, due to the possibility of diversifying and expanding the Brazilian energy matrix and reducing the consumption of fossil fuels and the emission of greenhouse gases (Bernal et al., 2017).

Several studies have reported the experience of developed countries in recovering biogas and using the produced energy to add energy, economic and financial benefits to the sewage treatment (Larson et al., 2016; Lindkvist and Karlsson, 2018). However, a great part of the biogas produced in STPs in developing countries is not used to produce energy, as observed in Brazil, where such use is still incipient and limited to a small number of treatment plants (Santos et al., 2016).

The sludge produced in STPs is also regarded as a feasible energy source by contributing self-sufficiency energy in STPs and reducing residue for the final destination (Yang et al., 2016). Sludge in Brazil is typically sent to landfills, disregarding among other issues its energy potential. In addition, the management of this by-product corresponds up to $60 \%$ of total operational expenses in an STP (Valente, 2015). For many countries of the EU, the use of thermal processes for the management of sludge produced in STPs, for energy purposes, is estimated to double by 2020, with 2012 as a base year, corresponding to around $37 \%$ of sludge management options (Kelessidis and Stasinakis, 2012). Therefore, it is expected that the sludge, usually characterized as the type of residue disposed of in landfills, will become an energy source, a paradigm change regarding its final destination (Gu et al., 2017). 
For Bernal et al. (2017) and Rosa et al. (2016), studying the energy recovery from byproducts generated in UASB reactors is important and can contribute to enhance the Brazilian energy matrix by using renewable sources from the sanitation sector.

Paraná State has the greatest number of UASB reactors in Brazil: 89\% (235) of the STPs use this technology, and treatment flows range from $3 \mathrm{~L} \mathrm{~s}^{-1}$ to $4032 \mathrm{~L} \mathrm{~s}^{-1}$, but only $0.4 \%$ of this potential is actually used to produce electricity (Sanepar, 2016). These numbers show the energy potential of the biogas produced as a result of anaerobic sewage treatment.

In order to enable and encourage energy recovery from by-products, mathematical models and Geographical Information Systems (GIS) can be useful tools to estimate and assess the energy potential of UASB reactors, as well as to improve studies on energy self-sufficiency in STPs and contribute to the decision-making process in sanitation management. GIS have been considered a powerful tool that allows, among other resources, the location of potential areas for biogas use, as recently carried out by Sahoo et al. (2018).

In Brazil, studies that evaluate the potential energy of by-products (biogas and sludge) in UASB reactors do not have geo-referenced information. When the energy potential is combined with operational and local issues, this could be essential for rapid assessment and diagnosis of its potential in different regions.

In this context, to provide a basis for the decision-making process in sanitation management in Brazil, and to promote the use of sewage treatment by-products to produce energy, this study assessed sludge and biogas energy potentials from UASB reactors in the state of Paraná, Brazil, and also verified spatial distribution using GIS based tools.

\section{MATERIALS AND METHODS}

\subsection{An overview of biogas energy recovery potential in STP based on UASB reactors}

First, an inventory of full-scale STPs that actually implemented the biogas energy recovery in Brazil was carried out. This survey was conducted using direct contact with Sanitation Companies that already promote electricity generation by the use of biogas as an energy source in 2018. The information requested includes the following: an installed wastewater treatment system, the actual population that is served and the average influent flow.

Afterwards, the STPs operated by UASB reactors with energy recovery of biogas was evaluated. It was then compared with the UASB installed capacity to treat domestic sewage in Brazil.

The current situation of biogas energy potential in STPs operated by UASB reactors was estimated using the actual population served. An estimate was also made of the full potential of biogas of STPs operated by UASB reactors associated with an installed capacity that would promote the energy recovery of this by-product. The unitary relationship of $133.8 \mathrm{MJ}^{\mathrm{inhab}}{ }^{-1}$ $\mathrm{y}^{-1}$ proposed by Lobato (2011) was used to determine the current and full energy potential of biogas.

After the overview that highlighted the biogas energy recovery at STPs in Brazil, the potential of renewable energy sources (biogas and sludge) was assessed in Paraná, the state with the highest number of full-scale UASB-based treatment plants. The evaluation was carried out using secondary data provided by the Water and Sanitation Company of Paraná State for 2016. The database consisted of sewage flow, dehydration units and STPs localization. The Geographic Information System (GIS) was used as a tool for the decision-making process in sanitation management. 


\subsection{Energy potential of biogas and sludge from UASB reactors in Paraná State}

The study was carried out in several STPs in Paraná State, Brazil. Out of the 239 currently operating STPs, 182 treat sewage using UASB reactors, of which only the Ouro Verde STP, which is able to treat up to $70 \mathrm{~L} \mathrm{~s}^{-1}$ of sewage, produces electricity from biogas.

Out of the 182 STPs assessed, 158 operate with drying beds and 8 operate with centrifuges; 16 units do not have dehydration systems. The sludge is sent to landfills or disposed in agricultural areas. The STPs were classified by size as "small" (lower than $56 \mathrm{~L} \mathrm{~s}^{-1}$ ), "medium" (from 57 up to $434 \mathrm{~L} \mathrm{~s}^{-1}$ ) and "large" (greater than $435 \mathrm{~L} \mathrm{~s}^{-1}$ ), according to the Paraná Environmental Institute (IAP) and CONAMA Resolution no. 377/2006.

Figure 1 shows spatially the STPs operated by UASB reactors in Paraná State according to their sizes.

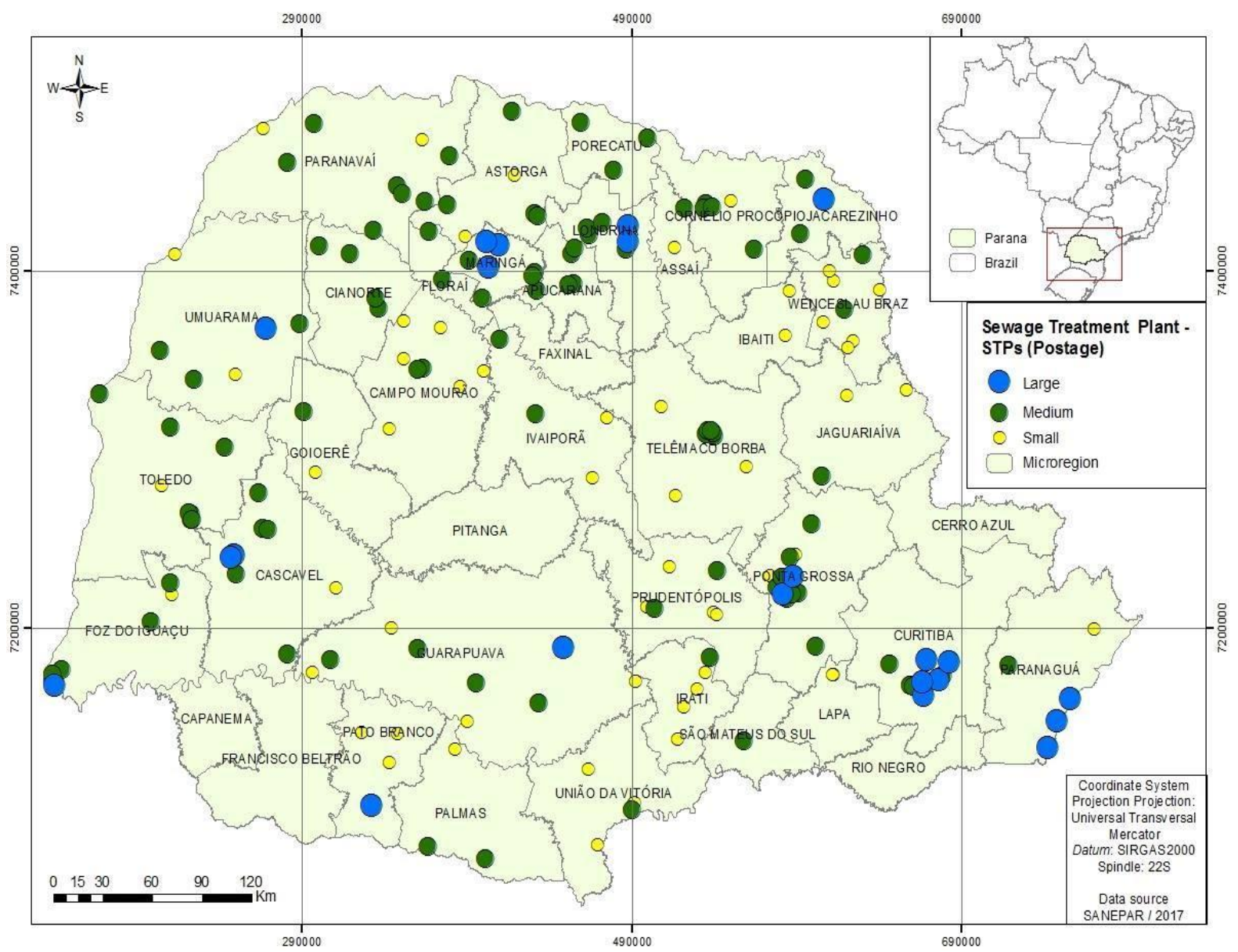

Figure 1. Location of STPs based on UASB reactors in Paraná State, according to their size.

\subsection{Energy potential of by-products (biogas and sludge)}

A mathematical model was structured in an electronic spreadsheet using the premises of simplicity and a reduced number of input data. The mathematical model was developed to estimate the energy potential of biogas and sludge in three scenarios that correspond to different sewage and reactor characteristics, namely: (i) worst scenario; (ii) typical scenario; and (iii) best scenario, as reported by Rosa et al. (2013).

\subsection{The input data of the model}

The variability of input data presented by value range (Table 1) was incorporated into the model through uncertainty analysis, which is based on the execution of a high number of 
simulations (in this case 250 simulations for each situation), called a "Monte Carlo" simulation. In each model execution, a different group of input values is selected randomly according to the uniform distribution within pre-established ranges.

Table 1. Input data of biogas and sludge used in the model.

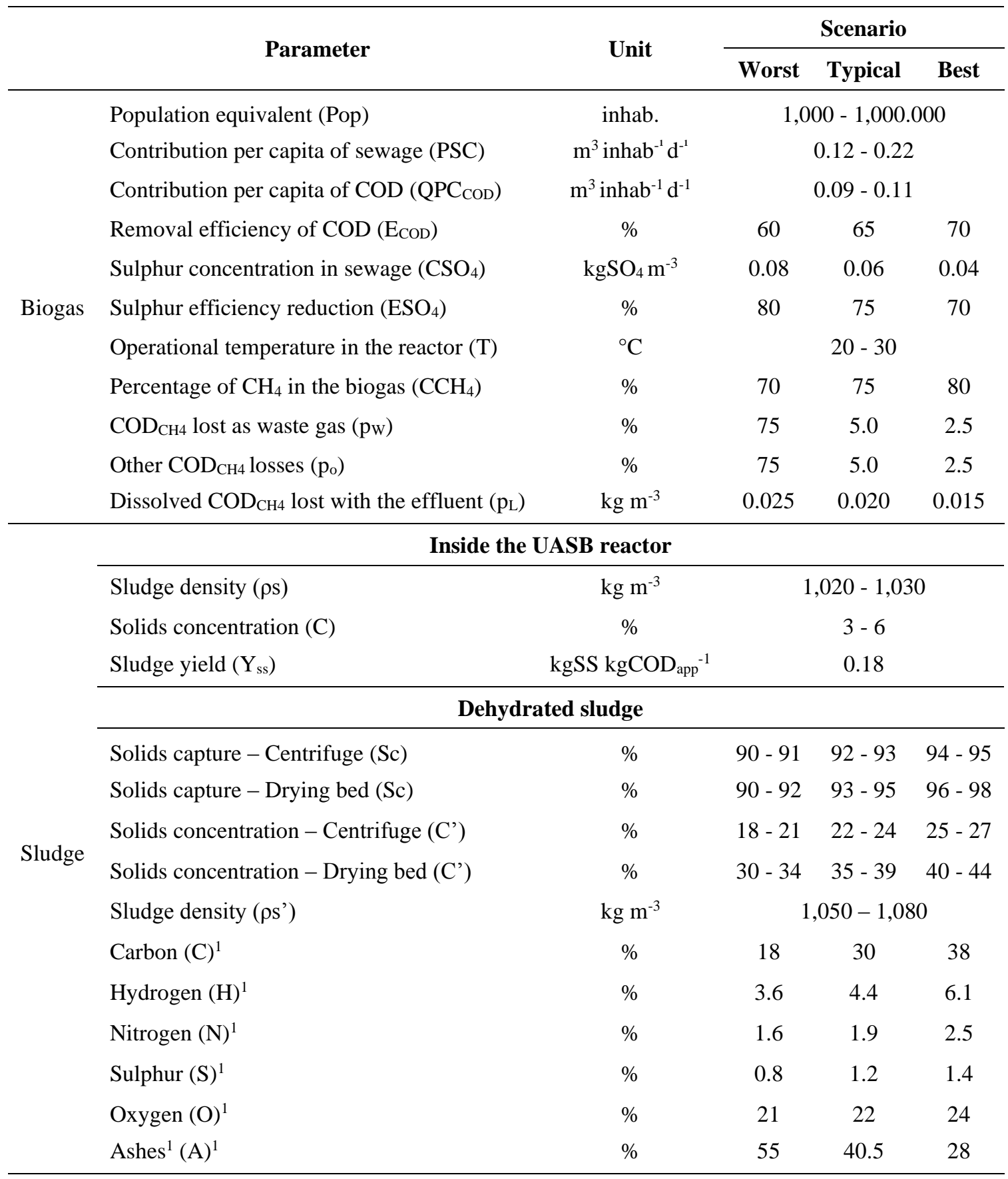

The model developed to estimate the energy potential of biogas was conceptually structured based on the COD conversion routes and methane flows in UASB reactors. The input data needed for calculating the energy potential of biogas were: population equivalent (Pop), per capita contribution of sewage (PSC), per capita contribution of COD (QPC $\left.{ }_{C O D}\right)$, removal efficiency of $\mathrm{COD}\left(\mathrm{E}_{\mathrm{COD}}\right)$, sulfate concentration in sewage $\left(\mathrm{C}_{\mathrm{SO}}\right)$, sulfate reduction efficiency (ESO4), reactor operational temperature $(\mathrm{T})$, percentage of $\mathrm{CH}_{4}$ in the biogas $\left(\mathrm{C}_{\mathrm{CH}} 4\right)$ and losses in the system ( $\left.\mathrm{p}_{\mathrm{W}}, \mathrm{p}_{\mathrm{o}}, \mathrm{p}_{\mathrm{L}}\right)$. The value ranges for the input data of the model were derived from a review of the literature as presented in Lobato et al. (2011). The calculation of mass energy 
balance parcels for COD and the biogas energy potential are presented by Lobato et al. (2012) (Table 2).

The following variables were considered for estimating the energy potential of sludge: density ( $\rho)$, solids concentration $(\mathrm{C})$; solids yield coefficient $(\mathrm{Y})$; solids capture in the dehydration unit (Sc) after dehydration; solids concentration (C'); density ( $\left.\rho s^{\prime}\right)$ and elemental composition. The value ranges for the elemental composition of the sludge were derived from a review of the literature as presented in Rosa et al. (2016). The calculation of energy potential of sludge are presented by Rosa et al. (2013) and transcribed in Table 3. The mathematical models for sludge and biogas were developed by Rosa et al. (2013) and Lobato et al. (2012), respectively. Since the models were validated by those authors, the simulated data regarding the energy potential of biogas and sludge are compatible with monitored data for STPs of different sizes.

The production of solids in UASB reactors (Ps) and the production of solids in dehydration (Ps') for mechanical dehydration alternatives (drying beds and centrifuges) were determined according to Von Sperling and Chernicharo (2005). The lower Calorific Values (LCV) were determined according to Cortez et al. (2008). The sludge energy potential takes into account the sludge production and the LCV, as presented in Table 3.

\subsection{The energy potential estimation of by-products in UASB reactors in Paraná State}

After running the mathematical model, 250 theoretical STPs were simulated and then (i) linear regressions were obtained for the simulated data to estimate the by-products energy potential considering the sewage flow; (ii) following these equations, the sewage flows of STPs in Paraná State were used to determine the biogas and sludge energy potential; and finally, (iii) the energy potential of the by-products was assessed for different sizes, scenarios and dehydration units. Thematic maps were used to represent the energy potential of the by-products in full-scale STPs in Paraná/Brazil by using the software ArcGIS ${ }^{\circledR} 10.2$, where the STPs' geographic locations, flows and energy potentials were converted into point-vector shapefiles (*shp). Using the Analysis Tools (Spatial Join), the spatial elements of the spreadsheet with the shapefile's attribute table were associated with the microregions of Paraná State and the classification of the potentials was performed. Thematic maps were designed considering STPs based on UASB reactors in Paraná State and the microregions were delimited according to the base system presented by the Brazilian Institute of Geography and Statistics (IBGE).

\section{RESULTS AND DISCUSSIONS}

\subsection{An overview of biogas energy recovery potential in STP based on UASB reactors}

In accordance with the evaluation done in Brazil, there are only ten full-scale STPs where biogas energy recovery is in process, as shown in Table 4. Out of the ten STPs, only four treat sewage using full-scale UASB-based treatment plants. These units are concentrated in the States of Minas Gerais, São Paulo and Paraná. Table 4 indicates the current- and full energy potential of biogas for the states. The state of Paraná presents the highest biogas energy potential, albeit only $0.4 \%$ of its potential is exploited. 
Table 2. Equations for calculating the portions of the mass balance of COD and energy recovery potential.

\begin{tabular}{|c|c|c|}
\hline Parcels & Equations & Notes \\
\hline Estimate of mean influent flow rate & $F_{\text {mean }}=$ Pop $\times$ PSC & $\begin{array}{l}\mathrm{F}_{\text {mean }}=\text { Mean influent flow rate }\left(\mathrm{m}^{3} \mathrm{~d}^{-1}\right) \\
\text { Pop }=\text { population (inhab. }) \\
\text { PSC }=\text { per-capita sewage contribution }\left(\mathrm{m}^{3} \text { inhab }^{-1} \mathrm{~d}^{-1}\right)\end{array}$ \\
\hline Estimate of daily COD mass removed from the system & $\begin{array}{l}C O D_{\text {remov }}=P \text { Pop } \times P S C \times C O D_{\text {inf }} \\
C O D_{\text {remov }}=F_{\text {mean }} \times C O D_{\text {inf }} \times E_{C O D}\end{array}$ & $\begin{array}{l}\mathrm{COD}_{\text {remov }}=\text { daily COD mass removed from the system }\left(\mathrm{kgCOD} \mathrm{d}^{-1}\right) \\
\mathrm{COD}_{\text {inf }}=\mathrm{COD} \text { concentration influent }\left(\mathrm{kgCOD} \mathrm{m}^{-3}\right) \\
\mathrm{E}_{\mathrm{COD}}=\text { efficiency of COD removal }(\%) \\
\mathrm{F}_{\text {mean }}=\text { mean influent flow rate }\left(\mathrm{m}^{3} \mathrm{~d}^{-1}\right)\end{array}$ \\
\hline Estimate of daily COD mass used by the biomass & $\begin{array}{c}C O D_{\text {sludge }}=C O D_{\text {remov }} \times Y_{C O D} \\
Y_{C O D}=Y T V S \times K_{T V S-C O D}\end{array}$ & $\begin{array}{l}\mathrm{COD}_{\text {sludge }}=\text { daily COD mass converted into biomass }\left(\mathrm{kgCOD}_{\text {sludge }} \mathrm{d}^{-1}\right) \\
\mathrm{Y}_{\mathrm{COD}}=\text { sludge yield, as COD }\left(\mathrm{kgCOD}_{\text {sludge }} \mathrm{kgCOD}_{\text {rem }}^{-1}\right) \\
\mathrm{Y}_{\mathrm{TVS}}=\text { sludge yield, as total volatile solids }(\mathrm{TVS})\left(\mathrm{kgTVS} \mathrm{kgCOD}_{\mathrm{rem}^{-1}}\right) \\
\mathrm{K}_{\mathrm{TVS}-\mathrm{COD}}=\text { conversion factor }\left(1 \mathrm{kgTVS}=1.42 \mathrm{kgCOD}_{\text {sludge }}\right)\end{array}$ \\
\hline Estimate of sulfate load converted into sulfide & $\mathrm{CO}_{\mathrm{SO}_{4} \text { converted }}=F_{\text {mean }} \times \mathrm{SOO}_{4} \times E_{\mathrm{SO}_{4}}$ & $\begin{array}{l}\mathrm{CO}_{\text {SO4converted }}=\text { load of } \mathrm{SO}_{4} \text { converted into sulfide }\left(\mathrm{kgSO}_{4} \mathrm{~d}^{-1}\right) \\
\mathrm{C}_{\mathrm{SO} 4}=\text { average influent } \mathrm{SO}_{4} \text { concentration }\left(\mathrm{kgSO}_{4} \mathrm{~m}^{-3}\right) \\
\mathrm{E}_{\mathrm{SO} 4}=\text { efficiency of sulfate reduction }(\%)\end{array}$ \\
\hline Estimate of daily COD mass used in sulfate reduction & 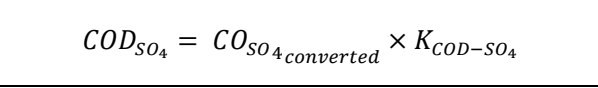 & $\begin{array}{l}\mathrm{COD}_{\mathrm{SO} 4}=\mathrm{COD} \text { used by the sulfate reducing bacteria for sulfate reduction }\left(\mathrm{kgCOD}_{\mathrm{SO} 4} \mathrm{~d}^{-1}\right) \\
\mathrm{K}_{\mathrm{COD}-\mathrm{SO} 4}=\mathrm{COD} \text { consumed in sulfate reduction }\left(0.667 \mathrm{kgCOD}_{\mathrm{SO} 4} \mathrm{kgSO}_{4}^{-2}\right)\end{array}$ \\
\hline Estimate of daily COD mass converted into methane & $\begin{array}{c}C O D_{C H_{4}}=C O D_{\text {remov }}-C O D_{\text {sludge }}-C O D_{S_{4}} \\
Q_{C H_{4}}=\frac{C O D_{C H_{4}} \times R \times(273+T)}{P \times K_{C O D} \times 1,000}\end{array}$ & $\begin{array}{l}\mathrm{COD}_{\mathrm{CH} 4}=\text { daily } \mathrm{COD} \text { mass converted into methane }\left(\mathrm{kgCOD}_{\mathrm{CH} 4} \mathrm{~d}^{-1}\right) \\
\mathrm{Q}_{\mathrm{CH} 4}=\text { theoretical volumetric production of methane }\left(\mathrm{m}^{3} \cdot \mathrm{d}^{-1}\right. \\
\mathrm{R}=\text { gas constant }\left(0.08206 \text { atm } \mathrm{Lmol}{ }^{-1} \mathrm{~K}^{-1}\right) \\
\mathrm{T}=\text { operational temperature of the reactor }\left({ }^{\circ} \mathrm{C}\right) \\
\mathrm{P}=\text { atmospheric pressure }(1 \mathrm{~atm}) \\
\mathrm{K}_{\mathrm{COD}}=\mathrm{COD} \text { of one mole of } \mathrm{CH}_{4}\left(0.064 \mathrm{kgCOD}_{\mathrm{CH} 4} \mathrm{~mol}^{-1}\right)\end{array}$ \\
\hline Estimate of methane loss & $\begin{array}{c}Q_{O-\mathrm{CH}_{4}}=Q_{\mathrm{CH}_{4}} \times p_{O} \\
Q_{W-C H_{4}}=Q_{C H_{4}} \times p_{w} \\
Q_{L-C H_{4}}=\text { Fmean } \times p_{L} \times f_{C H_{4}}\left(\frac{R \times(273+T)}{P \times K_{C O D}}\right) \\
p_{L}=\frac{\% C H_{4}}{100} \times k_{h} \times F_{S}\end{array}$ & $\begin{array}{l}Q_{W-C H 4}=\text { methane loss as waste gas }\left(\mathrm{m}^{3} \mathrm{~d}^{-1}\right) \\
p_{w}=\text { percentage of methane in the gaseous phase lost as waste gas }(\%) \\
Q_{o-C H 4}=\text { other methane losses in the gaseous phase }\left(\mathrm{m}^{3} \mathrm{~d}^{-1}\right) \\
p_{O}=\text { percentage of methane in the gaseous phase considered as other losses }(\%) \\
Q_{L-C H 4}=\text { loss of dissolved methane in the liquid effluent }\left(\mathrm{m}^{3} \mathrm{~d}^{-1}\right) \\
p_{L}=\text { concentration of dissolved methane in the liquid effluent }\left(\mathrm{kg} \mathrm{m}^{-3}\right) \\
f_{\mathrm{CH} 4}=\text { conversion factor of methane mass into COD mass }\left(4 \mathrm{kgCOD} \mathrm{kgCH}_{4}{ }^{-1}\right) \\
\mathrm{K}_{\mathrm{h}}=\text { constant of Henry }\left(\mathrm{mg}^{-1} \mathrm{~L}^{-1} \mathrm{~atm}^{-1}\right) \\
\mathrm{F}_{\mathrm{s}}=\text { supersaturation factor of } \mathrm{CH}_{4} \text { in the liquid phase } \\
\% \mathrm{CH}_{4}=\text { percentage of } \mathrm{CH}_{4} \text { in the biogas }\end{array}$ \\
\hline Estimate of actual methane production & $Q_{\text {actual-CH}}=Q_{C_{4}}-Q_{W-C H_{4}}-Q_{O-C H_{4}}-Q_{L-C H_{4}}$ & $Q_{\text {actual-CH4 }}=$ actual production of methane available for energy recovery $\left(\mathrm{m}^{3} \mathrm{~d}^{-1}\right)$ \\
\hline Energy recovery potential & $P E_{\text {actual }-\mathrm{CH}_{4}}=Q_{\mathrm{N}-\text { actual }-\mathrm{CH}_{4}} \times E_{\mathrm{CH}_{4}}$ & $\begin{array}{l}P E_{\text {actual-CH4 }}=\text { energy potential of biogas }\left(\mathrm{MJ} \mathrm{d}^{-1}\right) \\
Q_{N-\text { actual-CH4 }}=\text { normalized methane production }\left(\mathrm{Nm}^{3} \mathrm{~d}^{-1}\right) \\
E_{\mathrm{CH} 4}=\text { calorific energy of methane }\left(35.9 \mathrm{MJ} \mathrm{Nm}^{-3}\right)\end{array}$ \\
\hline
\end{tabular}


Table 3. Equations for calculating the energy potential of sludge.

\begin{tabular}{|c|c|c|}
\hline Parcels & Equations & Notes \\
\hline \multicolumn{3}{|c|}{ UASB reactor } \\
\hline \multirow[t]{2}{*}{ Influent COD load } & \multirow[t]{2}{*}{$C O D_{a p p}=P o p \times P C L_{C O D}$} & $\begin{array}{l}C O D_{a p p}=\mathrm{COD} \text { load applied to the system }\left(\mathrm{kgCOD} \mathrm{d}^{-1}\right) \\
\text { Pop = population (inhab.) }\end{array}$ \\
\hline & & $P C L_{C O D}=$ per capita contribution of COD $\left(\mathrm{kg} \cdot\right.$ inhab $\left.^{-1} \mathrm{~d}^{-1}\right)$ \\
\hline Sludge production & $P_{S}=C O D_{a p p} \times Y_{S S}$ & $\begin{array}{l}P_{s}=\text { sludge production in the system }\left(\mathrm{kg} \mathrm{SS} \mathrm{d}^{-1}\right) \\
Y_{S S}=\text { sludge yield }\left(0.18 \mathrm{kgSS} \mathrm{kg} \mathrm{CODapp}{ }^{-1}\right)\end{array}$ \\
\hline \multirow[t]{2}{*}{ Volumetric sludge production } & $V_{s}=\frac{P_{s}}{\left[\frac{C}{100}\right] \times \rho_{s}}$ & $\begin{array}{l}V_{s}=\text { volumetric sludge production }\left(\mathrm{m}^{3} \mathrm{~d}^{-1}\right) \\
C=\text { solids concentration in the sludge }(\%) \\
\rho_{s}=\text { sludge density }\left(\mathrm{kg} \mathrm{m}^{-3}\right)\end{array}$ \\
\hline & \multicolumn{2}{|c|}{ Dewatering processes } \\
\hline \multirow[t]{2}{*}{ Dry sludge production } & $P_{s}^{\prime}=\frac{S_{c}}{100} \times P_{s}$ & $\begin{array}{l}P_{s}^{\prime}=\text { sludge production in the dehydration unit }\left(\mathrm{kgSS} \mathrm{d}^{-1}\right) \\
S_{c}=\text { solids capture in the dehydration unit }(\%)\end{array}$ \\
\hline & \multicolumn{2}{|c|}{ Energy potential of sludge } \\
\hline \multirow[t]{2}{*}{ Theoretical HCV } & \multirow{2}{*}{$H C V=\frac{\left[337,3 \times C+1.418,9 \times\left(H-\frac{O}{8}\right)+93,1 \times S+23,3 \times N\right]}{1.000}$} & \multirow{2}{*}{$\begin{array}{l}H C V=\text { higher calorific value, }\left(\mathrm{MJ} \mathrm{kg}^{-1}\right) \text {, d.b. } \\
\text { Elemental composition } \\
C ; H ; O ; S ; N=\% \text { of carbon, hydrogen, oxygen, sulfur, nitrogen in the material, d.b. }\end{array}$} \\
\hline & & \\
\hline Theoretical LCV & $\begin{array}{l}L C V=\left[(H C V-\lambda \times(r+0,09 \times H))\left(100 W_{t}\right) / 100\right] \\
\qquad r=\frac{W_{t}}{\left(100-W_{t}\right)}\end{array}$ & $\begin{array}{l}L C V=\text { lower calorific value }\left(\mathrm{MJ} \mathrm{kg}^{-1}\right), \mathrm{m} . \mathrm{b} . \\
\lambda=\text { latent heat of water }\left(2,31 \mathrm{MJ} \mathrm{kg}^{-1} \text { in } 25^{\circ} \mathrm{C}\right) \\
r=\text { solids content and dehydrated sludge moisture ratio } \\
H_{s}=\text { hydrogen content }(\%) \text {, d.b. } \\
W_{t}=\text { solids content in the dehydrated sludge }(\%), \text { m.b. }\end{array}$ \\
\hline Sludge energy potential & $P E_{\text {sludge }}=L C V \times P_{s}^{\prime}$ & $P E_{\text {sludge }}=$ energy potential of sludge $\left(\mathrm{MJ} \mathrm{d}^{-1}\right)$ \\
\hline
\end{tabular}

d.b: dry basis, m.b: moist basis (real moisture of the sample after collection). 
Table 4. The summary of full-scale STPs in Brazil with energy recovery of biogas.

\begin{tabular}{|c|c|c|c|c|c|c|c|}
\hline Location & $\begin{array}{l}\text { Sanitation } \\
\text { company }\end{array}$ & STP & $\begin{array}{l}\text { Treatment } \\
\text { system }\end{array}$ & $\begin{array}{c}\text { Population } \\
\text { served (inhab.) }\end{array}$ & 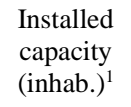 & $\begin{array}{c}\text { CEP } \\
\left(\mathrm{GJ} \mathrm{d}^{-1}\right)^{2}\end{array}$ & $\begin{array}{c}\text { FEP } \\
\left(\mathrm{GJ} \mathrm{d}^{-1}\right)^{3}\end{array}$ \\
\hline \multirow{5}{*}{ Minas Gerais } & \multirow{5}{*}{ COPASA } & Arrudas & Activated sludge & $1,343,867$ & \multirow{5}{*}{$4,049,193$} & \multirow{5}{*}{218} & \multirow{5}{*}{1,484} \\
\hline & & Betim & UASB & 266,495 & & & \\
\hline & & & & & & & \\
\hline & & Ibirité & Activated sludge & 115,604 & & & \\
\hline & & Vieira/ Montes Claros & UASB & 326,931 & & & \\
\hline \multirow{5}{*}{ São Paulo } & & Barueri & Activated sludge & $4,400,000$ & \multirow{5}{*}{$5,520,818$} & \multirow{5}{*}{161} & \multirow{5}{*}{2,024} \\
\hline & SABESP & & & & & & \\
\hline & & Franca & Activated sludge & $4,100.000$ & & & \\
\hline & SEMAE & São José do Rio Preto & UASB & 438,000 & & & \\
\hline & AMBIENT & Ribeirão Preto & Activated sludge & 620,000 & & & \\
\hline \multirow{3}{*}{ Paraná } & \multirow{3}{*}{ SANEPAR } & Belém & Activated sludge & 600,000 & \multirow{3}{*}{$7,300,603$} & \multirow{3}{*}{11} & \multirow{3}{*}{2,676} \\
\hline & & & & & & & \\
\hline & & Ouro Verde & UASB & 29,500 & & & \\
\hline
\end{tabular}

${ }^{1}$ Installed capacity in STPs based on UASB reactors for the states (Chernicharo et al., 2018). ${ }^{2}$ Current energy potential (CEP $=$ Population served by UASB reactors $* 133.8 * 0.001 / 365)$. ${ }^{3}$ Full energy potential $(\mathrm{FEP}=$ Installed capacity of UASB reactors $* 133.8 * 0.001 / 365)$.

\subsection{Potential of renewable energy sources in Paraná, Brazil}

\subsubsection{Overall energy potential of the STP}

Table 5 presents a summary of the linear regression relationships obtained for the simulated data to estimate the by-products' energy potential considering sewage flow. According to the characteristics described for the worst scenario that indicates no free energy after sludge combustion, there are not any applicable regression equations. This could be due to high level of ash, low concentration of hydrogen, low level of fixed solids and low solids concentration.

The use of the model allowed the simulation of the energy potential of biogas and dehydrated sludge in units with drying beds and centrifuges for different sizes of STPs, for the three scenarios considered for the sewage flow of STPs in Paraná State.

Table 5. Summary of linear regressions obtained for various proposed relations for biogas and sludge.

\begin{tabular}{|c|c|c|c|c|c|c|c|c|}
\hline \multirow{3}{*}{ By-product } & \multirow{3}{*}{ System } & \multirow{3}{*}{ Relation (x,y) } & \multicolumn{6}{|c|}{ Scenario } \\
\hline & & & \multicolumn{2}{|l|}{ Worst } & \multicolumn{2}{|c|}{ Typical } & \multicolumn{2}{|l|}{ Best } \\
\hline & & & Equation & $\left(\mathrm{R}^{2}\right)$ & Equation & $\left(\mathrm{R}^{2)}\right.$ & Equation & $\left(\mathrm{R}^{2}\right)$ \\
\hline Biogas & - & $\mathrm{L} \mathrm{s}^{-1} \times \mathrm{MJ} \mathrm{d}^{-1}$ & $y=129.46 x$ & 0.98 & $y=180.91 x$ & 0.73 & $y=244.09 x$ & 0.82 \\
\hline \multirow{2}{*}{ Sludge } & DB & $\mathrm{L} \mathrm{s}^{-1} \times \mathrm{MJ} \mathrm{d}^{-1}$ & $y=4.96 x$ & 0.78 & $y=108.82 x$ & 0.88 & $y=186.23 x$ & 0.89 \\
\hline & $\mathrm{C}$ & $\mathrm{L} \mathrm{s}^{-1} \times \mathrm{MJ} \mathrm{d}^{-1}$ & \multicolumn{2}{|c|}{ Not applicable } & $y=7,50 x$ & 0.84 & $y=21,25 x$ & 0.86 \\
\hline
\end{tabular}

DB: drying bed; C: centrifuge. 


\subsubsection{Biogas energy potential}

Among the 182 STPs based on UASB reactors in Paraná State, 61 were classified as "small", 99 as "medium" and 22 as "large". The energy potential of small STPs for the typical scenario was $380 \mathrm{GJ} \mathrm{d}^{-1}$. Medium- and large STPs presented biogas energy potentials of 2,869 $\mathrm{GJ} \mathrm{d}^{-1}$ and 4,871 GJ d ${ }^{-1}$, respectively, for the typical scenario. Despite the lower number of units, the large STPs (22 units) presented the highest biogas energy potential in Paraná State, 13 times higher than that of small STPs and 1.7 times higher than that of medium STPs. Considering a conversion yield of $30 \%$ by the power generator and the typical scenario, Paraná State could produce $677 \mathrm{MWh} \mathrm{d}^{-1}$ of electricity, enough to supply the energy demand around 111,000 inhabitants on the basis of a per capita energy consumption of $0.0061 \mathrm{MWh} \mathrm{d}^{-1}$ (Balanço Energético Nacional, 2017). Figure 2 presents the accumulated biogas energy potential of STPs, considering the different scenarios and sizes.

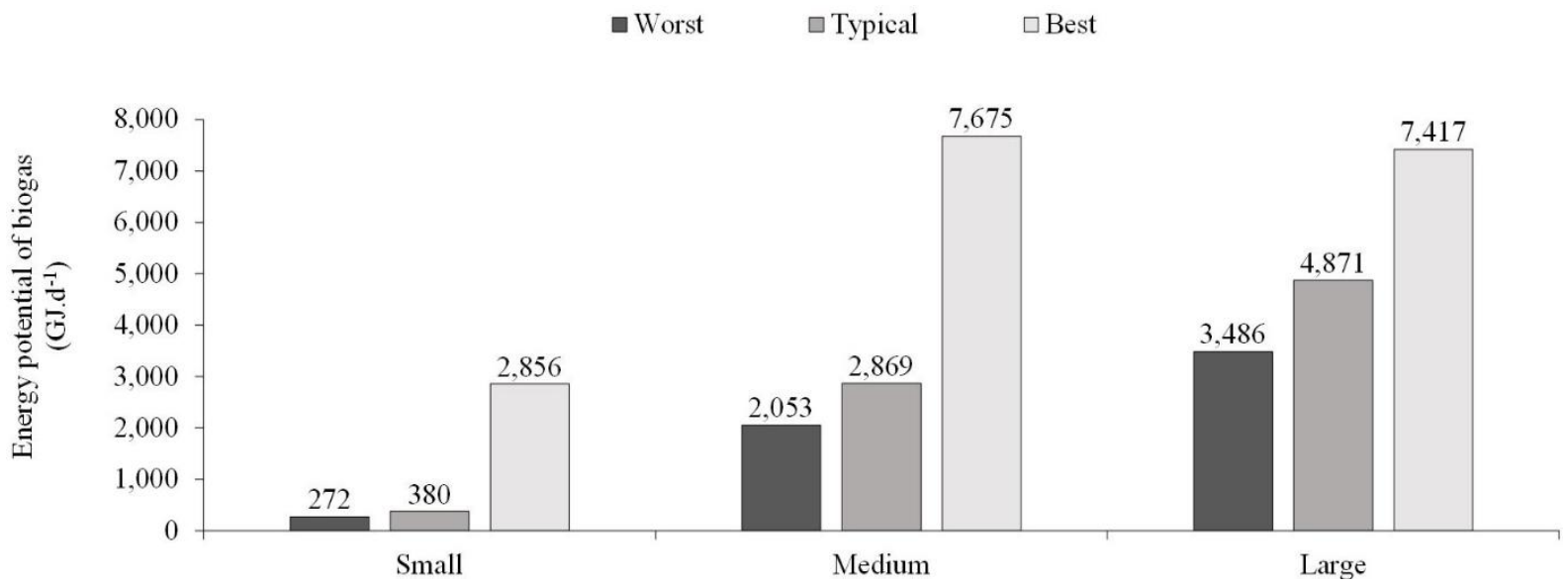

Figure 2. Biogas energy potential for the different scenarios and STP sizes in Paraná State.

Ouro Verde STP generates electricity from biogas in Paraná, but it produces only $0.4 \%$ of the maximum capacity to be achieved by a medium-size STP. For small- and large STPs, there are no records of biogas recovery for energy purposes, which indicates the need for investments in energy recovery at STPs, regardless of their size.

The analysis of the 99 medium-sized STPs resulted in mean energy potentials of 19, 29 and $39 \mathrm{GJ} \mathrm{d}^{-1}$ for the worst, typical and best scenarios, respectively. For the typical scenario, $74 \%$ of the STPs presented biogas energy potential of up to $38 \mathrm{GJ} \mathrm{d}^{-1}$.

As previously mentioned, despite the lower number of STPs classified as "large" (22), all of them presented higher biogas potential in comparison to small- and medium STPs. The mean energy values obtained from the biogas energy recovery in large STPs corresponded to 142, 221 and $299 \mathrm{GJ} \mathrm{d}^{-1}$ for the worst, typical and best scenarios, respectively.

Figure 3 presents the biogas energy potential for the STPs in each microregion of Paraná for the typical scenario. By estimating the energy potential of the biogas produced by UASB reactors, it is possible to outline strategic plans for future investments in the energy recovery of the by-products. Most of the STPs (124 units) presented biogas energy potentials below $30 \mathrm{GJ}$ $\mathrm{d}^{-1}$ and 19 STPs presented potentials higher than $100 \mathrm{GJ} \mathrm{d}^{-1}$. The microregions of Curitiba and Londrina presented the highest biogas-energy potentials, more than $1,000 \mathrm{GJ} \mathrm{d}^{-1}$, and the microregion of Curitiba accounted for $30 \%$ of the entire state's potential. 


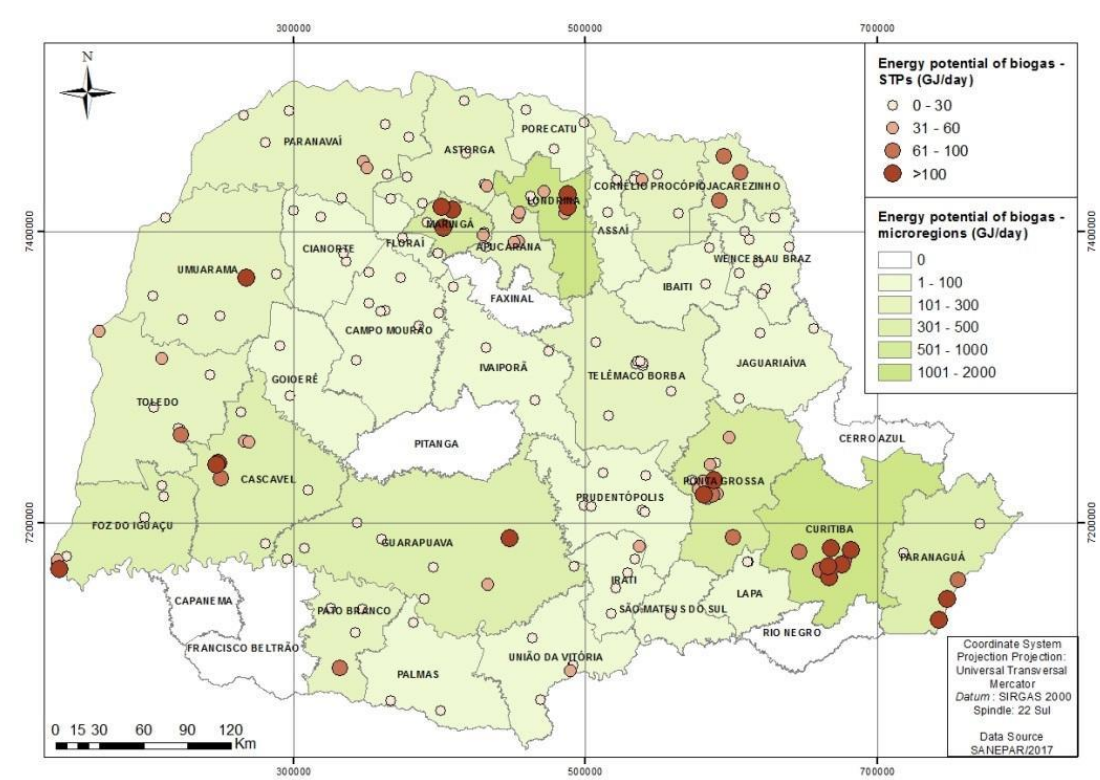

Figure 3. Biogas energy potentials for STPs in each microregion of Paraná State.

\subsubsection{Sludge energy potential}

For sludge management, $87 \%$ of the STPs use drying beds for the dehydration process, of which 33\% (52 STPs) are small, 58\% (91 STPs) are medium and 9\% (15 STPs) are large. According to the typical scenario, the accumulated sludge energy potential for small, medium and large STPs corresponded to $205 \mathrm{GJ} \mathrm{d}^{-1}, 1,613 \mathrm{GJ} \mathrm{d}^{-1}$ and 1,582 $\mathrm{GJ} \mathrm{d}^{-1}$, respectively, indicating that the medium- and large STPs presented the highest potentials for energy recovery from this by-product. Figure 4 presents the accumulated energy potential of the dehydrated sludge removed from the drying beds, considering the different STP sizes and scenarios assessed.

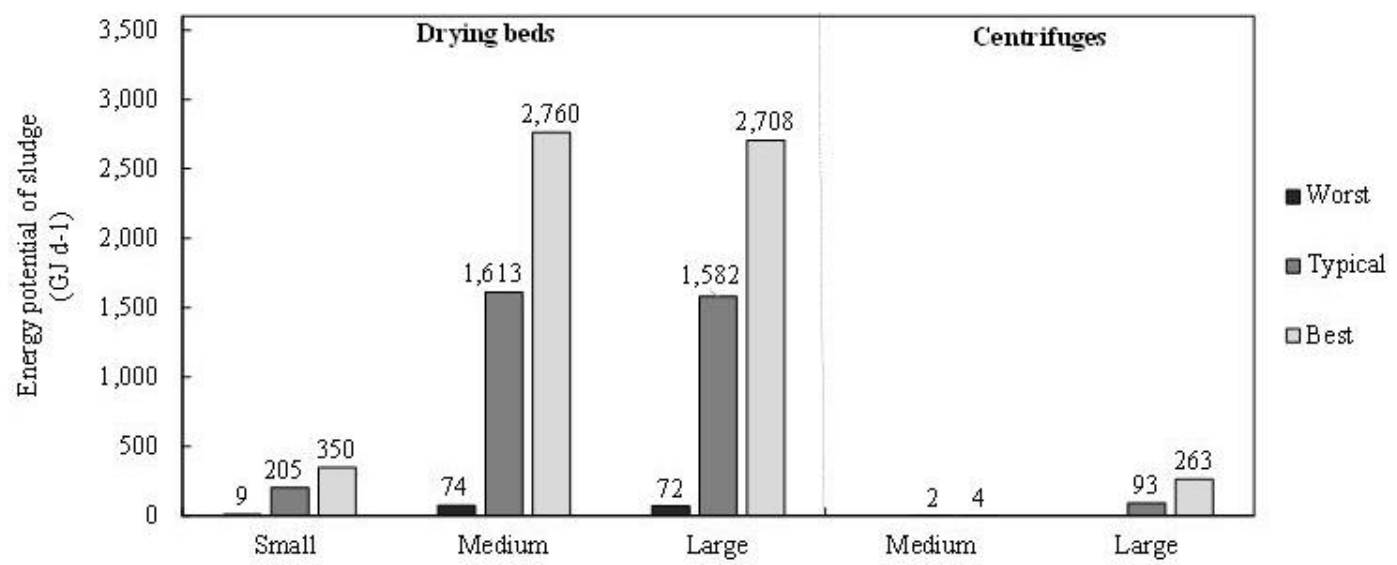

Figure 4. Sludge energy potential for the different scenarios and sizes of STPs that use drying beds and centrifuges for dehydration, in Paraná.

Also, small STPs presented mean values of $0.2,3.9$ and $6.7 \mathrm{GJ} \mathrm{d}^{-1}$ for the worst, typical and best scenarios, respectively. Overall, the use of drying beds instead of centrifuges points to a greater interest in sludge recovery from the energy aspect, because of the lower levels of moisture in the sludge cake.

Figure 4 shows the full energy potential of sludge from 8 STPs operated with centrifuges in Paraná State for the different scenarios. An absence of small STPs with centrifuges as the dehydration system is seen. 
Considering STPs where the dehydration is performed by centrifuges, the large size presented the highest potential. The 7 STPs would produce for the typical and best scenarios around 263 to $93 \mathrm{GJ}$ day $^{-1}$. In the worst scenario the dehydrated sludge does not contribute useful energy after its combustion due to the higher moisture of the material.

The medium STPs presented a low contribution in terms of energy potential owing to the presence of only one unit operated by centrifuge. Finally, the sludge energy potential for typical- and best scenarios were around 2 and $4 \mathrm{GJ} \mathrm{day}^{-1}$, respectively.

Figure 5 presents the sludge potential for the STPs based on UASB reactors in each microregion of Paraná State, considering the energy of this by-product in the different dehydration units (drying beds and centrifuge) for the typical scenario.

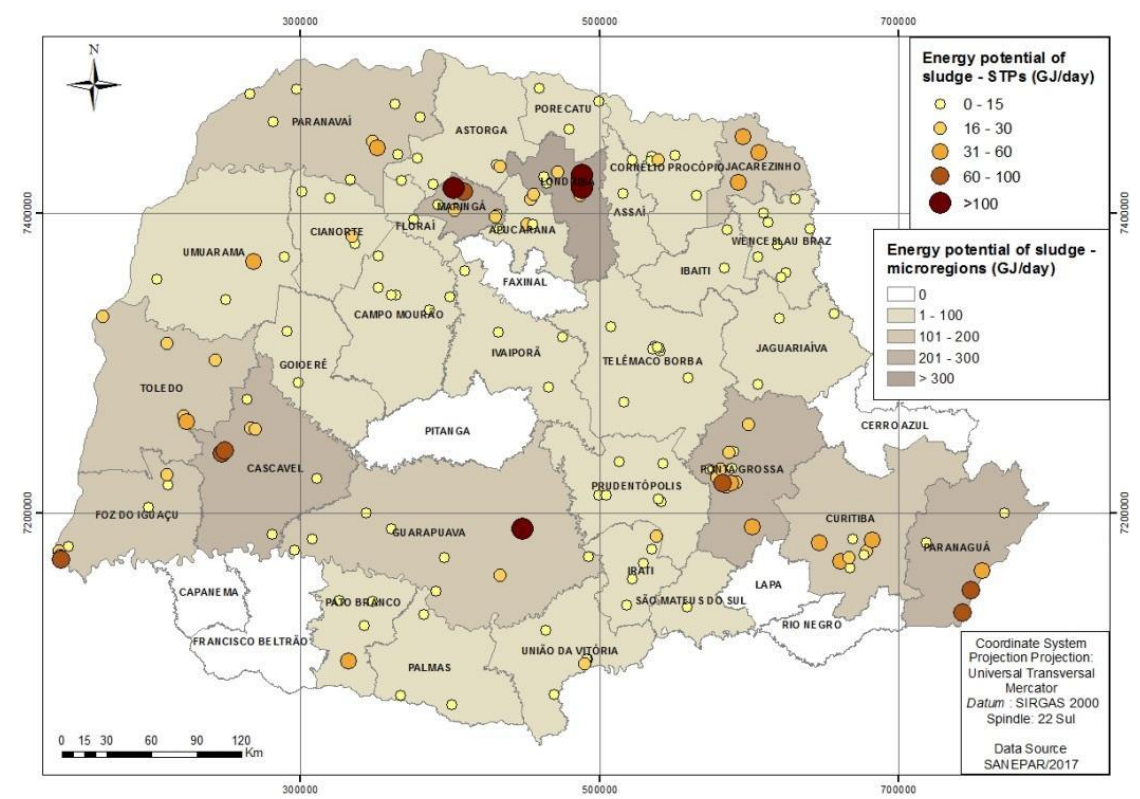

Figure 5. Spatial distribution of the energy potential of the sludge produced in UASB reactors in Paraná.

Most of the STPs in Paraná State presented sludge energy potentials below $15 \mathrm{GJ} \mathrm{d}^{-1}$. However, 4 STPs presented potentials higher than $100 \mathrm{GJ} \mathrm{d^{-1 }}$. This analysis enables the diagnosis of the sludge energy potential and the encouragement of its recovery, which leads to better strategic plans for investment in sludge final destination. The microregions of Curitiba and Londrina presented the highest energy potentials, of more than $300 \mathrm{GJ} \mathrm{d}^{-1}$.

\subsubsection{By-products energy potential}

For all STP sizes, there was a predominance of biogas over sludge in terms of energy potential. Biogas corresponded to 65,64 and $74 \%$ of the energy contained in the by-products of small-, medium- and large STPs, respectively. For the 158 STPs that use drying beds for dehydration, the mean biogas potential corresponded to $64 \%$ of the by-products potential, whereas for the 8 STPs that use centrifuges, biogas accounted for $95 \%$ of the total potential. Valente (2015) also reports that biogas is the most representative by-product in terms of energy. Rosa et al. (2016) observed a similar tendency at the Laboreaux STP (medium-sized), where the energy potentials of sludge and biogas were $7,518 \mathrm{MJ} \mathrm{d}^{-1}$ and $10,962 \mathrm{MJ} \mathrm{d}^{-1}$, respectively, with $60 \%$ of the energy associated with biogas.

\subsection{Perspectives on the energy recovery in UASB reactors in Brazil}

Considering the growing use of UASB reactors in Brazil, and the expansion of basic sanitation, the relevance of energy recovery from sludge and biogas is evident. Despite the 
proven energetic characteristics of the sludge and biogas from UASB, energy self-sufficiency in STPs and the evident financial viability (Valente, 2015), there are several limiting conditions for such practices in Brazil.

Moreira et al. (2017), after verifying the strategic demands in terms of biogas recovery in Brazil, observed the need for qualified training for operators, sanitation managers and designers. Furthermore, there is an evident need for qualified professionals who can operate STPs that employ biogas recovery, given the complex operation and monitoring of such systems. Moreover, the technological alternatives (measurement and monitoring equipment, among others) are not national, thus professional qualification not aligned with the demands of the sanitation sector and the limitations in technical assistance compromise the expansion of resource recovery in Brazilian STPs.

Possetti et al. (2018) highlight the use of some engineering practices that would increase biogas recovery by maximizing the sustainable and clean energy in Brazil. For these authors, some improvements in the design, construction and operation of UASB reactors could be pointed out, such as: construction of three-phase separator, sealing and water-tightness of biogas pipe, methane recovery from the liquid phase, scum removal, installation of efficient biogas burners, measuring and monitoring of biogas.

Despite the discussed factors, a change of paradigm is expected with the increase of research on resource recovery from effluent treatment, as well as the greater visibility of the subject in the sanitation sector by sanitation and engineering companies and by the society. The progressive updating, although modest, of environmental legislation, norms and guidelines for the recovery of by-products and residues from the sanitation sector, as well as the creation of the National Institute of Science and Technology in Sustainable Sewage Treatment Plants is also evident.

Lastly, the use of GIS to evaluate the energy potential proved to be an easy tool to identify sites with high potential for energy recovery. The application of this tool for this purpose was carried out in other studies, as pointed by Zoreei (2018), who indicated the advantages of its use. The mapping could be used to diagnose the energy potential of by-products in UASB reactors based on geographic location and is also useful in strategic plans and decision-making in sanitation companies.

\section{CONCLUSIONS}

In spite of the advanced level of sewage treatment in the Paraná, there is considerable energy potential for by-products (sludge and biogas) from UASB reactors to be exploited.

The States of São Paulo, Minas Gerais and Paraná include all of the STPs that exploit energy recovery of biogas, though their potential is not sufficiently explored. Paraná State presents the highest biogas potential; however, it recovers only $0.4 \%$ of its capacity for 2018 .

There are few large STPs in Paraná State, but they correspond to the highest potentials of energy recovery from sludge and biogas, and biogas was the main energy by-product.

GIS is a relevant tool for sanitation companies and its use can enable studies for the implementation of energy self-sufficiency projects by allowing analyses of energy recovery byproducts that take spatial distribution into consideration

The studies of energy recovery from biogas and sludge provide the sanitation companies with support for the decision-making process, and show the energetic advantages of UASB reactors that are currently not exploited.

Energy recovery from the main sewage treatment technology in Brazil (UASB reactors) is incipient. Paraná State is at the forefront of energy recovery from biogas and sludge, but it still presents low levels of STP energy self-sufficiency.

Rev. Ambient. Água vol. 15 n. 1, e2398 - Taubaté 2020 


\section{ACKNOWLEDGMENT}

The authors thank the Brazilian government agencies: Cnpq (Conselho Nacional de Desenvolvimento Científico e Tecnológico), FAPEMIG (Fundação de Amparo à Pesquisa do Estado de Minas Gerais), Coordenação de Aperfeiçoamento de Pessoal de Nível Superior Brasil (CAPES) - Código de Financiamento 001 and Sanepar (Companhia de Saneamento do Paraná) and INCT ETEs Sustentáveis.

\section{REFERENCES}

BERNAL, A. P. et al. Vinasse biogas for energy generation in Brazil: An assessment of economic feasibility, energy potential and avoided $\mathrm{CO} 2$ emissions. Journal of Cleaner Production, v. 151, p. 260-271, 2017. https://doi.org/10.1016/j.jclepro.2017.03.064

CHERNICHARO, C. A. L. et al. Panorama do tratamento de esgoto sanitário nas regiões Sul, Sudeste e Centro-Oeste do Brasil: tecnologias mais empregadas. DAE, v. 66, n. 214, 2018. http://dx.doi.org/10.4322/dae.2018.028

CORTEZ, L. A. B.; LORA, E. E. S; GÓMEZ, E. O. (Org.). Biomassa para energia. Campinas: Editora da UNICAMP, 2008. 732 p.

GU, Y. et al. The feasibility and challenges of energy self-sufficient wastewater treatment plants. Applied Energy, v. 204, p. 1463-1475, 2017. https://doi.org/10.1016/j.apenergy.2017.02.069

KELESSIDIS, A.; STASINAKIS, A. S. Comparative study of the methods used for treatment and final disposal of sewage sludge in European countries. Waste Management, v. 32, n. 6, p. 1186-1195, 2012. https://doi.org/10.1016/j.wasman.2012.01.012

KHAN, A. A. et al. Sustainable options of post treatment of UASB effluent treating sewage: A review. Resources, Conservation and Recycling, v. 55, n. 12, p. 1232-1251, 2011. https://doi.org/10.1016/j.resconrec.2011.05.017

LARSSON, M.; GRÖNKVIST, S.; ALVFORS, P. Upgraded biogas for transport in Sweden Effects of policy instruments on production, infrastructure deployment and vehicle sales. Journal of Cleaner Production, v. 112, p. 3774-3784, 2016. https://doi.org/10.1016/j.jclepro.2015.08.056

LINDKVIST, E.; KARLSSON, M. Biogas production plants; existing classifications and proposed categories. Journal of Cleaner Production, v. 174, p. 1588-1597, 2018. https://doi.org/10.1016/j.jclepro.2017.10.317

LOBATO, L. C. S.; CHERNICHARO, C. A. L.; SOUZA, C. L. Estimates of methane loss and energy recovery potential in anaerobic reactors treating domestic wastewater. Water Science and Technology, v. 66, n. 12, p. 2745-2753, 2012. https://doi.org/10.2166/wst.2012.514

LOBATO, L. C. S. Energy recovery from biogas produced in UASB reactors treating domestic wastewater. 2011. 187f. Tese (Doutorado em Saneamento, Meio Ambiente e Recursos Hídricos) - Universidade Federal de Minas Gerais, Belo Horizonte, 2011.

MOREIRA, H. C. Diretrizes de capacitação para o uso de biogás de esgoto no Brasil. Revista DAE, v. 66, n. 209, p. 134-150, 2018. 
POSSETTI, G. R. C. et al. Contribuição para o aprimoramento de projeto, construção e operação de reatores UASB aplicados ao tratamento de esgoto sanitário - Parte 5: Biogás e emissões fugitivas de metano. Revista DAE, v. 66, n. 214, p. 73-89, 2018.

ROSA, A. P. Recovery of biogas and sludge from UASB reactors as renewable energy in sewage treatment plants. 2013. $172 \mathrm{f}$. Tese (Doutorado em Saneamento, Meio Ambiente e Recursos Hídricos) - Universidade Federal de Minas Gerais, Belo Horizonte, 2013.

ROSA, A. P. et al. Energy potential and alternative usages of biogas and sludge from UASB reactors: Case study of the Laboreaux wastewater treatment plant. Water Science and Technology, v. 73, n. 7, p. 1680-1690, 2016. https://doi.org/10.2166/wst.2015.643

ROSA, A. P. et al. Assessing the potential of renewable energy sources (biogas and sludge) in a full-scale UASB-based treatment plant. Renewable Energy, v. 124, p. 21-26, 2018. https://doi.org/10.2166/wst.2015.643

SAHOO, K. et al. GIS-based assessment of sustainable crop residues for optimal siting of biogas plants. Biomass and Bioenergy, v. 110, n. April 2017, p. 63-74, 2018. https://doi.org/10.1016/j.biombioe.2018.01.006

SANEPAR. Relatório de Administração e Sustentabilidade 2016. 2016. Available at: http://site.sanepar.com.br/a-sanepar/sanepar-em-numeros. Access: 20 Jan. 2018.

SANTOS, I. F. S. DOS; BARROS, R. M.; TIAGO FILHO, G. L. Electricity generation from biogas of anaerobic wastewater treatment plants in Brazil: An assessment of feasibility and potential. Journal of Cleaner Production, v. 126, p. 504-514, 2016. https://doi.org/10.1016/j.jclepro.2016.03.072

VALENTE, V. B. Análise de viabilidade econômica e escala mínima de uso do biogás de reatores anaeróbios em estações de tratamento de esgoto no Brasil. 2015. $182 \mathrm{f}$. Dissertação (Mestrado em Planejamento Energético) - Universidade Federal do Rio de Janeiro, 2015.

VON SPERLING, M.; CHERNICHARO, C.A.L. Biological wastewater treatment in warm climate regions. London: IWA Publishing, 2005.

YANG, Q., DUSSAN, K., MONAGHAN, R. F., ZHAN, X. Energy recovery from thermal treatment of dewatered sludge in wastewater treatment plants. Water Science and Technology, v. 74, n. 3, p. 672-680, 2016. https://doi.org/10.2166/wst.2016.251

ZAREEI, S. Evaluation of biogas potential from livestock manures and rural wastes using GIS in Iran. Renewable energy, v. 118, p. 351-356, 2018. https://doi.org/10.1016/j.renene.2017.11.026 